\title{
The Perplex of Deforestation in sub-Saharan Africa
}

\author{
A.W. Yalew* \\ Dresden Leibniz Graduate School, Leibniz Institute of Ecological Urban and Regional Development, \\ TU Dresden, Germany
}

Date Received: 08-10-2014 Date Accepted: 10-05-2015

\begin{abstract}
Deforestation has been a complex phenomenon to study in sub-Saharan Africa. The average annual deforestation rate in the region is by far higher than the world average. What causes and drives deforestation in the region are debated to date. The present paper is motivated by this debate. It attempts to test whether the maintained hypotheses on the causes of deforestation can give answer to the problem in sub-Saharan Africa. It used average cross-national data of forty eight countries in the region. The data are retrieved from international sources. The Spearman's rank correlation coefficients between two deforestation indicators and five often-cited causes of deforestation were computed. The role of public forest ownership, share of forest and agricultural products in total exports, and the year of forest laws enacted are also discussed. However, it finds no clear, strong, and systematic pattern to argue that population density, rural population, rural poverty, industrial logging for exports, economic growth, late enactment of forest laws, and public ownership of forests are underlying causes of deforestation in the region. The trends of forestland in Rwanda and Zimbabwe vividly present the finding. Therefore, future studies related to the topic in the region shall focus on sub-national panel data.
\end{abstract}

Keywords: deforestation, population, economy, institutions, sub-Saharan Africa

\section{Introduction}

Deforestation is one of the major environmental problems in sub-Saharan Africa (SSA). The share of forest area in SSA has declined from 29.3\% in 1990 to 26.1\% in 2007 (World Bank, 2010). Africa has lost about 3.4 million hectares of forest each year in 2000-2010 (FAO, 2010). The average annual rate of deforestation of the region $(0.8 \%)$ is still by far higher than the world average $(0.15 \%)$ in 1990-2010 (FAO, 2010). Nevertheless, Africa has settled at the bottom in terms of public expenditure on forest sector per hectare (FAO, 2010). In contrast of its clear trend, however, deforestation in SSA has been a very complex phenomenon to study (Sieboek, 2002; Rudel, 2013). What exactly causes deforestation in the region is open to debate. With poor score to halt deforestation and scientific consensus on what causes and exacerbates deforestation in the region, the success of recent forest management initiatives such as Clean Development Mechanism (CDM) and Reducing Emissions from Deforestation and forest Degradation (REDD and REDD+) will be questionable because, without proper understanding of true causes, effective policies cannot be designed and implemented (Pearce,

\footnotetext{
*Correspondence: a.yalew@dlgs.ioer.de
}

Tel: +4935146342349

ISSN 2235-9370 Print/ISSN 2235-9362 Online @ U University of Sri Jayewardenepura 
2001). Among others, testing the maintained theoretical hypothesis that links different demographic, economic, and institutional factors with deforestation helps to identify and understand the root causes of deforestation in the region. This is the main motivation of this paper. For data consistency and completeness, international data sources, World Bank, FAO, OECD, and Penn World Tables were used. It uses two methods of analysis. First, each maintained hypothesis was tested against the data from SSA. However, it finds no clear, strong, and systematic correlation to argue that population density, rural population, rural poverty, industrial logging for exports, economic growth, late enactment of forest laws, and public ownership of forests as underlying causes of deforestation in SSA. Second, partial rank correlation coefficients (Spearman's rho) were calculated for orderable factors. But, it only affirms the afore mentioned conclusion. The findings based on average cross-national data undermine the importance of incumbent hypothesis to explain the deforestation in SSA. At the same time, it is hardly possible to provide simple generalisation on the relative importance of some factors over the others. Therefore, future studies should focus on sub-national panel data. Better research funds should be available from SSA countries themselves to unpin researchers from international data. The rest of the paper is organised as follows. Section 2 discusses the methodology while Section 3 presents and discusses the results. The conclusions are given in Section 4.

\section{Methodology}

\subsection{Data and data sources}

The study used secondary data from international sources on forests, demographic, economic, and institutional indicators. The demographic, economic, and institutional factors considered here are based on the theoretical and empirical literature on the causes of deforestation in tropical regions (Butler and Laurance, 2008; Titenberg, 2000; Laurance, 1999), in the SSA region (Rudel, 2013; Mitchard and Flintrop, 2013; Diarrassouba and Boubacar, 2009; Boahene, 1998; Barnes, 1990) and countries in the SSA (Sieböck, 2002; Rusing, 2000).

Table 1: Description of the data and data sources.

\begin{tabular}{|c|c|c|c|c|}
\hline Variable & Description & Measure & Data of & Data source \\
\hline Lfa & $\begin{array}{l}\text { Net loss of forest area as percentage of total land } \\
\text { area }\end{array}$ & $\%$ & $2007 \& 1990$ & World Bank 2010 \\
\hline$A d r$ & Average annual rate of deforestation & $\%$ & $1990-2010$ & FAO 2005, 2010 \\
\hline$Y S F L$ & Year of specific forests laws was enacted & Year & Country specific & FAO 2010 \\
\hline$P b c$ & Share of total forest under public ownership & $\%$ & 2005 & FAO 2010 \\
\hline$P v t$ & Share of total forest under private ownership & $\%$ & 2005 & FAO 2010 \\
\hline Othr & $\begin{array}{l}\text { Share of total forest under other than public \& } \\
\text { private }\end{array}$ & $\%$ & 2005 & FAO 2010 \\
\hline Egr & $\begin{array}{l}\text { Average annual economic growth rate (at } 2005 \\
\text { price) }\end{array}$ & $\%$ & 1990-2007 & Heston et al. 2009 \\
\hline Ge & Average government effectiveness & Index & $1996-2012$ & Kaufmann et al. 2013 \\
\hline$A g / G D P$ & Average share of agriculture in GDP & $\%$ & $1990-2010$ & World Bank 2013 \\
\hline $\operatorname{Exp}$ & $\begin{array}{l}\text { Share of forest and agricultural commodities in the } \\
\text { total exports }\end{array}$ & $\%$ & 2008 & OECD 2010 \\
\hline$P d$ & $\begin{array}{l}\text { Population density (Number of people per square } \\
\text { kilometer) }\end{array}$ & $\%$ & $2004 \& 2008$ & FAO 2005, 2010 \\
\hline $\operatorname{Pr}$ & Rural Population (\% total population a country) & $\%$ & $2004 \& 2008$ & FAO 2005, 2010 \\
\hline Prp & $\begin{array}{l}\text { Rural poverty ( } \% \text { of rural poor in the total rural } \\
\text { population of a country) }\end{array}$ & $\%$ & $\begin{array}{l}1990-2010 \text { (of } \\
\text { available years) }\end{array}$ & $\begin{array}{l}\text { OECD 2010, World } \\
\text { Bank } 2010\end{array}$ \\
\hline
\end{tabular}


The international data sources were preferred for comprehensiveness of factors and consistency of the data. Data is averaged overtime to compensate the missed as well as lagged effects of the factors. Table 2 below summarises the data.

Table 2: Summary of data.

\begin{tabular}{|c|c|c|c|c|c|c|c|c|c|c|c|c|c|}
\hline \multirow[b]{2}{*}{ Country } & \multicolumn{2}{|c|}{ Forests } & \multicolumn{3}{|c|}{ Demographic } & \multicolumn{3}{|c|}{ Economic } & \multicolumn{5}{|c|}{ Institutional } \\
\hline & Lfa & Adr & $\mathrm{Pd}$ & $\operatorname{Pr}$ & Prp & $\mathrm{Ag} / \mathrm{GDP}$ & Egr & Exp & $\mathrm{Ge}$ & $\mathrm{Pbc}$ & Pvt & Othr & YSFL \\
\hline Angola & 1.97 & 0.2 & 12.6 & 53 & 94 & 9.63 & 3.8 & 0 & -1 & 100 & 0 & 0 & 1955 \\
\hline Benin & 9.95 & 1.1 & 70.2 & 57 & 33 & 33.7 & 1.1 & 38 & -0 & 99 & 1 & 0 & 1993 \\
\hline Botswana & 3.55 & 1 & 3.03 & 44 & NA & 3.48 & 2.9 & 0 & 0.6 & 24 & 5 & 71 & 1968 \\
\hline Burkina Faso & 1.49 & 1 & 50.6 & 81 & 52 & 35.2 & 2 & 63 & -1 & 100 & 0 & 0 & 1997 \\
\hline Burundi & 6.05 & 2.2 & 300 & 90 & 37 & 45.3 & -2 & 53 & -1 & 100 & 0 & 0 & 1985 \\
\hline Cameroon & 7.91 & 1 & 37.6 & 45 & 50 & 22.8 & -1 & 15 & -1 & 100 & 0 & 0 & 1994 \\
\hline Cape Verde & -6.6 & -1.4 & 122 & 42 & 55 & 10.9 & 5 & 0 & -0 & 100 & 0 & 0 & NA \\
\hline Central African Rep & 0.81 & 0.1 & 6.67 & 59 & NA & 52.1 & -1 & 46 & -2 & 91 & 0 & 9 & 2008 \\
\hline Chad & 1.07 & 0.7 & 8.01 & 74 & 67 & 31.5 & 3.8 & 95 & -1 & 100 & 0 & 0 & 2008 \\
\hline Comoros & 4.08 & 7.5 & 366 & 68 & NA & 44.3 & -1 & 63 & -1 & 100 & 0 & 0 & NA \\
\hline Congo & 0.85 & 0.1 & 11.2 & 43 & 58 & 7.58 & -0 & 0 & -1 & 100 & 0 & 0 & 2000 \\
\hline Cote d'Ivorie & -0.7 & -0.1 & 59.5 & 53 & NA & 25.8 & -1 & 29 & -1 & 99 & 1 & 0 & 1965 \\
\hline Djibouti & 0 & 0 & 33.9 & 15 & 49 & 3.49 & 0.4 & 24 & -1 & 100 & 0 & 0 & NA \\
\hline DR Congo & 3.33 & 0.2 & 26.1 & 67 & 76 & 48.2 & -6 & 0 & -2 & 100 & 0 & 0 & 2002 \\
\hline Equatorial Guinea & 9.22 & 0.7 & 20.5 & 56 & NA & 28.2 & 23 & 0 & -1 & 100 & 0 & 0 & 1997 \\
\hline Eritrea & 0.57 & 0.3 & 46.7 & 79 & NA & 20 & 0.7 & 8 & -1 & NA & NA & NA & 2006 \\
\hline Ethiopia & 1.97 & 1.1 & 72 & 84 & 45 & 52.1 & 1.6 & 54 & -1 & 100 & 0 & 0 & $\mathrm{NA}$ \\
\hline Gabon & 0.67 & 0 & 5.67 & 15 & 45 & 6.8 & -1 & 1 & -1 & 100 & 0 & 0 & 2001 \\
\hline Gambia & -3.3 & -0.4 & 155 & 59 & 63 & 22.7 & 0.4 & 49 & -1 & 94 & 6 & 0 & 1998 \\
\hline Ghana & 9.5 & 2.1 & 97.8 & 52 & 39 & 39 & 1.8 & 43 & -0 & 100 & 0 & 0 & 1998 \\
\hline Guinea & 3.08 & 0.5 & 36.4 & 65 & NA & 22.1 & 0.7 & 0 & -1 & 99 & 1 & 0 & 1989 \\
\hline Guinea-Bissau & 5.84 & 0.5 & 55.3 & 68 & NA & 56 & 0.9 & 93 & -1 & 100 & 0 & 0 & 1991 \\
\hline Kenya & 0.37 & 0.3 & 62.5 & 69 & 49 & 29.3 & 0.3 & 22 & -1 & 39 & 61 & 0 & 2005 \\
\hline Lesotho & -0.1 & -0.5 & 63.8 & 79 & NA & 13.9 & 2.5 & 54 & -0 & 14 & 0 & 86 & 1998 \\
\hline Liberia & 10.6 & 0.7 & 37.4 & 46 & NA & 67.8 & -2 & 13 & -2 & 100 & 0 & 0 & 1973 \\
\hline Madagascar & 1.6 & 0.4 & 31.4 & 72 & 74 & 28.4 & -1 & 17 & -0 & 98 & 2 & 0 & 1997 \\
\hline Malawi & 5.95 & 0.9 & 138 & 82 & 47 & 35.6 & 1.1 & 67 & -1 & NA & NA & NA & 1997 \\
\hline Mali & 1.39 & 0.6 & 9.89 & 68 & 76 & 42.2 & 2 & 77 & -1 & 100 & 0 & 0 & 1995 \\
\hline Mauritania & 0.16 & 3.3 & 2.92 & 48 & 61 & 32 & 0.9 & 0 & -0 & 97 & 3 & 0 & 2007 \\
\hline Mauritius & 1.18 & 0.3 & 620 & 57 & NA & 7.76 & 3.8 & 29 & 0.6 & 48 & 52 & 0 & 1983 \\
\hline Mozambique & 1.08 & 0.5 & 26.2 & 63 & 55 & 30.6 & 3.4 & 0 & 0.5 & 100 & 0 & 0 & 1999 \\
\hline Namibia & 1.52 & 0.9 & 2.74 & 65 & NA & 10.6 & 1.4 & 0 & 0.1 & NA & NA & NA & 2001 \\
\hline Niger & 0.56 & 1.9 & 10.8 & 81 & 66 & 39.4 & -0 & 0 & -1 & 100 & 0 & 0 & 2002 \\
\hline Nigeria & 7.65 & 3.3 & 160 & 52 & NA & 37.2 & 3.1 & 0 & -1 & 100 & 0 & 0 & $\mathrm{NA}$ \\
\hline Rwanda & -8.8 & -1.9 & 367 & 81 & 63 & 38.1 & 2.8 & 30 & -1 & 79 & 21 & 0 & 1988 \\
\hline Sao Tome and Principe & 0 & 0 & 167 & 51 & NA & 18.6 & 0.2 & 68 & -1 & NA & NA & NA & NA \\
\hline Senegal & 3.97 & 0.5 & 58.7 & 54 & NA & 18.1 & 0.9 & 0 & -0 & 100 & 0 & 0 & 1998 \\
\hline Seychelles & 0 & 0 & 186 & 47 & NA & 3.33 & 2.7 & 0 & 0 & 77 & 23 & 0 & 1955 \\
\hline Sierra Leone & 4.59 & 0.9 & 77 & 61 & 79 & 50.9 & -2 & 0 & -1 & 14 & 86 & 0 & 1988 \\
\hline Somalia & 2.08 & 1 & 14.9 & 64 & NA & NA & -2 & 26 & -2 & NA & NA & NA & NA \\
\hline South Africa & 0 & 0 & 39.3 & 41 & NA & 3.6 & 1.6 & 0 & 0.7 & 60 & 40 & 0 & 1998 \\
\hline Sudan & 4.21 & 0.3 & 15.7 & 59 & NA & 37.4 & 3.6 & 0 & -1 & 91 & 9 & 0 & 2002 \\
\hline Swaziland & -4.6 & -0.9 & 66.6 & 76 & 75 & 10.6 & 1.5 & 35 & -1 & 78 & 22 & 0 & 2001 \\
\hline Tanzania & 7.91 & 1.1 & 44.7 & 69 & 39 & 37.6 & 2.1 & 12 & -0 & 100 & 0 & 0 & 2002 \\
\hline Togo & 6.23 & 4.6 & 105 & 61 & NA & 36.8 & -1 & 56 & -1 & 27 & 73 & 0 & 2008 \\
\hline Uganda & 7.46 & 2.4 & 146 & 86 & 42 & 36.2 & 3.4 & 39 & -0 & 32 & 68 & 0 & 2003 \\
\hline Zambia & 10.2 & 0.3 & 15.6 & 64 & 74 & 21.5 & 2.5 & 0 & -1 & 100 & 0 & 0 & 1973 \\
\hline Zimbabwe & 13.8 & 1.8 & 33 & 64 & 48 & 17.8 & -2 & 12 & -1 & 63 & 37 & 0 & 1949 \\
\hline SSA average & 2.92 & 0.84 & 85.4 & 61 & 58 & 28.2 & 1.3 & 26 & -1 & 84 & 12 & 4 & \\
\hline
\end{tabular}

Source: Author compilation based on sources given in Table 1.

NA: data not indicated in these data sources. Zero values in column 9 do imply the forest and agricultural (raw or processed) items are not reported in the first three main export items of that country. 


\subsection{Research method}

The overall method of analysis is comparing and contrasting the relative position of a country (or a group of countries) in terms of deforestation and in terms of sources of deforestation which are demographic, economic, and institutional variables. In that way, if a country (or a group of countries) is placed in close positions in terms of deforestation and hypothesised cause of deforestation, then that specific hypothesis holds true in SSA. In other words, the nearer is the distance between the ranks, the more is that demographic, economic or institutional factor is responsible for deforestation in the region.

First, each hypothesis linking a demographic, economic, or institutional factor with deforestation is compared with the empirical data in SSA. Such discussion helps to see the role of factors where ranking makes less sense. For example, all forests are under public ownership right in half of the countries. In addition, for some factors like rural poverty, data is available for only 28 countries.

Then, partial rank correlation coefficients between the two deforestation indicators and five often-cited drivers of deforestation are computed. Partial rank correlation coefficients (Spearman's rho, $\rho)$ measure the dependence between two orderable variables. For a sample size of $n$, rank correlation coefficient is computed as in equation 1:

$$
\rho=1-\frac{6 \cdot \sum_{i}^{n} d i^{2}}{n\left(n^{2}-1\right)}
$$

where: $\quad d_{i}=$ the difference between the ranks of the dependent variable and the independent variable

The dependent variable is either of the two deforestation indicators. The independent variable is any of the five socio-economic factors. For deforestation, countries are ranked from highest to lowest value. The rank of countries for the socio-economic factors is from the expected association with the rank of deforestation. For instance, government effectiveness was ranked from worse (negative) to better (positive) as deforestation is expected to be higher in countries with ineffective governments. The ranks are given in Table 3 in the following section.

\section{Results and Discussion}

\subsection{Maintained hypotheses versus empirical data in SSA}

Population and deforestation

Population and its growth have been argued long to cause deforestation in developing countries (Laurance, 1999; Pearce, 2001). Increase in population increases demand for agricultural products and hence agricultural land. The search for extra agricultural land induces forest clearance. If the population growth specially happens in rural areas, it increases the fuelwood demand which still threatens forest (Barnes, 1990). In addition, as population increases the demand for industrial wood products will increase which in turn escalates the industrial logging. Hence, the fact that population and its growth puts pressure on the environment is indisputable. Nevertheless, linking population and its growth directly with deforestation is oversimplification (Sieböck, 2002). Therefore, population density may better metrics (Sieböck, 2002). Therefore, average population density (number of peoples per square kilometer) was used as proxy to population pressure on forestlands. 
Only Mauritius (620), Rwanda (367), Comoros (366), and Burundi (300) have population density greater than $200 \mathrm{~km}^{-2}$. Among the four, Burundi lost $6 \%$ forest area (\% total land) in the period of 1990-2007. While the average annual deforestation rate (1990-2010) is $2.2 \%$ well above the world and SSA average rate of deforestation in the two decades. The net loss of forest area in Comoros is $4.08 \%$ (1990-2007) but with highest annual rate of deforestation 7.5\% (1990-2010). Linking population density and deforestation is also cogent enough to explain the deforestation (in terms of both indicators) in Uganda, Nigeria, Malawi, and Togo which all have population density between 100 and 200, and rate of deforestation above the SSA's average. In contrast, this maintained hypothesis cannot explain for the case of Rwanda, Seychelles, Sao Tome and Principe, Gambia, and Cape Verde which still do have population density above $100 \mathrm{~km}^{-2}$ but gained net area of forest in terms of both indicators in the period.

Alternatively, we can test the hypothesis if there is no or little deforestation in countries with low population density. The average annual deforestation rate in Mauritania, a country with the lowest population density $\left(3 \mathrm{~km}^{-2}\right)$, is $2.7 \%$. The population density in Zimbabwe, which lost about $13 \%$ forest area and annual deforestation rate $1.8 \%$, is $39 \mathrm{~km}^{-2}$. Likewise, Equatorial Guinea, Cameroon, Niger, Liberia, and Benin do have population density below SSA's average (which is $85 \mathrm{~km}^{-2}$ ). Whereas the deforestation rates in this countries are above the SSA average in both indicators of deforestation. In sum, the empirical data supports little to generalise that population density is a main force behind deforestation in SSA.

\section{Rural Poverty and deforestation}

Natural resources represent important part of the asset base of the poor (Pearce, 2001). Many poor families find many forest products (timber, herbal medicines, fruits, and firewood) in the basket of their basic necessities (Diarrassouba and Buobacar, 2009). Thus, poor always tend to place higher discount rate on environment (Nayak, 2004). Nor rural poor invest in land development (Sieböck, 2002). Rural peasants will see forestland as an opportunity to become landowner (Tietenberg, 2000). Therefore, some tend to conclude that poverty is the primary cause of deforestation in the tropics (Diarrassouba and Buobacar, 2009). Rural population (\% national population) and rural poverty were taken as a proxy to rural society. We consider each in turn.

The average rural population in SSA is $61 \%$ of the total population. The two countries with lowest rural population are Djibouti (14.5\%) and Gabon (15.3\%). Coincidentally the deforestation (in terms of both indicators) in both countries is negligible. Of the 26 nations with proportion of rural population higher than SSA's average, only 12 of them have experienced average annual rate of deforestation higher than the SSA's average. In contrast, in 14 countries that loss of 5\% and higher, only 5 have rural population which is higher than the SSA's average.

Cameroon, Liberia, Ghana, Nigeria, and Benin have low percentage of rural population but higher deforestation rate (in both measures) compared to Rwanda, Lesotho, and Swaziland which have higher rural population percentage. Countries placed at bottom in terms of rural population $(<40 \%)$ Uganda, Ghana, Tanzania, Burundi, and Benin assumes the reverse rank in terms of deforestation. Rural poverty data was available only for 28 countries. Even though about $60 \%$ rural population lived under poverty, Rwanda and Swaziland still gained forest areas. Republic of Congo and Cape Verde have rural poverty ratio higher than Zimbabwe, Malawi, and Ethiopia but scored better when it comes to deforestation. 
Taken together, the analysis based on average data offers no systematic relationship between rural population and rural poor and deforestation in SSA. Being poor and rural dweller is not a sufficient reason to be blamed for deforestation. This goes with Angelsen et al. (1999) (cited in Sieböck, 2002) which finds that there is little empirical evidence to support that poverty is the underlying cause of deforestation. Nayak (2004) also finds no clear pattern between poverty and environmental degradation in rural India. Opposite to this, there are even some experiences in which rural and poor community has used forests and other natural resources in very sustainable manner (Sieböck, 2002). Especially if forest (other natural resources) management power is devolved to the local community, forests can successfully be used in poverty reduction beyond controlling deforestation (Shyamsundar et al., 2005).

\section{Agriculture and deforestation}

Shifting cultivation for subsistence agriculture, cash crops cultivation, and overgrazing involve clearing forests. One way to look at the linkage between agriculture and deforestation is through what happens to forests in countries which heavily depends on agricultural products, i.e., livestock, sesame, coffee, cocoa, cotton, cashew nuts, tea, fruits, flower cuts, tobacco, and sugar cane exports. As to 2008, agricultural commodities are among the three main export items in 21 SSA countries (OECD, 2010). Of these countries, only 10 exhibit average deforestation rate higher than the SSA average. This leaves us with no strong evidence in defense of tradable cash crop cultivation is underlying cause of deforestation in SSA. Another way to test the linkage is through the share of agriculture in Gross Domestic Product (GDP) and deforestation ${ }^{1}$. Agriculture accounts more than $30 \%$ of GDP in 13 of the 18 SSA nations with higher average rate of deforestation. In 10, out of 14 countries with high forest area lost, agriculture contributes more than $30 \%$.

Excepting Botswana, in all countries where agriculture contribution less than $10 \%$ of GDP, deforestation is meager. Another exception is the situation in Zimbabwe and Rwanda where, respectively, agriculture contributes $17 \%$ and $38 \%$ of GDP. This contrasts the $13 \%$ loss and $8.7 \%$ gain, respectively in Zimbabwe and Rwanda. Keeping these exceptions, the view that agricultural encroachment causes or triggers deforestation loosely explains the situation in SSA.

\section{Industrial logging and deforestation}

Industrial logging without tree replacement depletes forest (Butler and Laurance, 2008; Tietenberg, 2000; Laurance, 1999). Commercial logging also opens up previously inaccessible forests for new settlers which exacerbates deforestation. In addition, industrial forest products are seen as means of generating foreign exchange earnings for debt repayment in low-country income countries (Tietenberg, 2000). This premise holds true for SSA where industrial logging is primary for export. Thus, we can intertwine the two views together. The view whether industrial logging leads to deforestation in SSA can be captured by the deforestation in countries where forest products constitute the three main export items. Forest products (lumber, tropical hardwoods and natural rubber latex) are among the three main export items in Cameroon (8.1\% of total exports), Liberia (12.8\% of total exports) Central Africa Republic (45.5\% of total exports), and Chad (94\% of total exports). The deforestation

\footnotetext{
${ }^{1}$ Agriculture, value added (\% of GDP) here corresponds to ISIC divisions 1-5 and it includes forestry, hunting, and fishing, as well as cultivation of crops and livestock production. Value added is the net output of a sector after adding up all outputs and subtracting intermediate inputs. It is calculated without making deductions for depreciation of fabricated assets or depletion and degradation of natural resources (World Bank, 2013).
} 
data, however, shows the reverse. Thus, linking industrial logging and the share of forest products export directly, therefore, may be oversimplification as the discussion here does not substantiate the industrial logging-deforestation nexus in Titenberg (2000) and Laurance (1998). However, it goes in line with (Sieböck, 2002) which pointed "there are several examples for commercial logging operators carrying out sustainable forest management in the tropics such as Precious Woods in Costa Rica and the Amazon or Compagnie Équatoriale des Bois (CEB) Thanry in Gabon".

\section{Economic growth and deforestation}

Economic growth imposes detrimental effects on forests especially in countries where forest and agricultural products take the largest share in total exports and real GDP. In other words, if high economic growth rate is recorded in countries with high rate of deforestation (or net loss of forest area), then the share of agriculture in GDP and/or agricultural and forest products in total exports in the same countries is expected to be high ${ }^{2}$.

Agriculture contributes more than 50\% of the GDP in Liberia, Guinea-Bissau, Central Republic Africa, Ethiopia, and Sierra Leone. While forest products constitute among the three main export items in Liberia and Central Republic Africa, agricultural products are among the three main exports in Ethiopia, Guinea-Bissau, and Liberia. Therefore, economic growth, if it happens, in Liberia, Central Republic Africa, Ethiopia, and Guinea-Bissau would trigger deforestation either due direct export purpose and/or due to land encroached for agricultural purpose. Liberia is highly deforested in both indicators but with only $-2 \%$ average rate of real GDP growth.

Guinea-Bissau has lost about $6 \%$ of its forest area (\% of total land area), but scored only $0.9 \%$ average rate of real GDP growth. Alternatively, we can see whether countries with high deforestation rate (and at the same time high GDP growth rate) are dependent on agriculture and forests for livelihood and export. Equatorial Guinea scored an average of 23\% real GDP growth rate and lost $9 \%$ of its forest area ( $\%$ total land area). However, neither agricultural nor forest items are mentioned in the three main export items in Equatorial-Guinea.

On the reverse, forest products constitute $94 \%$ of the total export in Chad and ranked fourth in terms of real GDP growth rate $(3.77 \%)$. But, the deforestation rate in Chad is modest. This leaves us with little evidence to conclude that economic growth causes or exacerbates deforestation in agriculture and forest dependent nations in SSA.

\section{Weak institutions and deforestation}

Very recent studies in the environment-society nexus place more on emphasis on the role of institutions and governance. Accordingly, lack of good governance drives of deforestation rather than industrial logging, rural poverty, and agricultural encroachment per se (Sieböck, 2002). This lack of governance in forest management is manifested through lack of government commitment, corrupted and rent-seeking bureaucrats and bureaucracy, weak monitoring and law enforcement, political instability, and highly centralised power structures. Three indicators of institutional aspects were considered here. These are Government Effectiveness (GE) indicator, the years of forest laws enacted, and public ownership of forest in different countries of the region.

\footnotetext{
${ }^{2}$ The economic growth rate after 2007 is excluded in order to control the effect of global financial and economic crisis especially on oil and mineral exporting nations so that will not affect the ranking and, the economic growth rates refer to real GDP growth rates measured at 2005 price (Heston et al., 2009).
} 
GE is one of the six major Worldwide Governance Indicators calculated and updated since 1996 by Kaufmann and others. ${ }^{3}$ GE reflects "perceptions of the quality of public services, the quality of the civil service and the degree of its independence from political pressures, the quality of policy formulation and implementation, and the credibility of the government's commitment to such policies" (Kaufmann et al., 2013).

The value of GE ranges between -2.5 (weak) and 2.5 (strong). Somalia (-2.05) scores the most ineffective government and South Africa (0.66) the better one. However, deforestation in Somalia is far less than deforestation in Ghana, Benin, Tanzania, and Uganda where the average GE indicates good governance even by the SSA standard.

Early year of specific forest law enactment indicates early acknowledgment of the problem. Then, it is natural to presume that efforts to have been placed to arrest the problem since the specific forest laws are introduced in the country. Zimbabwe (in 1949), Liberia (in 1976), Burundi (in 1985) (1993), Cameroon (1994) are among the pioneers to enact specific of forest laws but unable to halt deforestation in 1990-2010. Out of 15 nations that enacted in 2000-2008, only four, Togo, Mauritania, Uganda, Tanzania and Niger reported high deforestation rate. In sum, it can be concluded that neither higher government effectiveness nor earlier implementation of forest laws have saved forests in SSA.

Private property right regime leads efficient and sustainable use of natural resources (Tietenberg, 2000). In other words, public ownership and management of natural resources (or forests in our case) may be sources of deforestation. Government failure for sustainable forest management can easily be captured if deforestation is high in countries with high percentage of public ownership and management of forests. Deforestation in Togo (73\% non-public) and Uganda (86\% non-public) is as high as the deforestation in Nigeria, Ghana or Liberia where all forests are owned by the public. Deforestation in South Africa, Seychelles, Swaziland and Rwanda where 80\% and 60\% are public is almost negligible. Though public ownership is Zimbabwe than in Rwanda and Swaziland, deforestation in the former is by far higher than the latter.

Therefore, we see that neither private nor public ownership per se can be blamed for deforestation. In closing, the qualitative discussion does support little the maintained hypotheses on the causes and drivers of deforestation in developing countries. The following section goes further to check the validity of the discussion in this section by computing partial correlation coefficients between the two deforestation indicators and five orderable factors.

\footnotetext{
${ }^{3}$ The six dimensions include: voice and accountability, political stability and absence of violence/terrorism, government effectiveness, regulatory quality, rule of law and control of corruption. All the available data (1996-2012) is used to compensate for the years in 1990-1995.
} 
Yalew /Journal of Tropical Forestry and Environment Vol. 5. No 01 (2015) 19-30

Table 3: Rank of countries.

\begin{tabular}{|c|c|c|c|c|c|c|c|}
\hline Country & Lfa & Adr & Egr & Ag/GDP & $\mathrm{Pd}$ & $\mathrm{Ge}$ & $\operatorname{Pr}$ \\
\hline Zimbabwe & 1 & 9 & 47 & 35 & 31 & 16 & 23 \\
\hline Liberia & 2 & 21 & 45 & 1 & 28 & 3 & 41 \\
\hline Zambia & 3 & 30 & 14 & 31 & 37 & 22 & 21 \\
\hline Benin & 4 & 10 & 23 & 20 & 16 & 38 & 31 \\
\hline Ghana & 5 & 7 & 18 & 11 & 13 & 42 & 37 \\
\hline Equatorial Guinea & 6 & 20 & 1 & 26 & 35 & 6 & 32 \\
\hline Tanzania & 7 & 11 & 15 & 13 & 25 & 37 & 13 \\
\hline Cameroon & 8 & 14 & 36 & 28 & 27 & 26 & 42 \\
\hline Nigeria & 9 & 3 & 9 & 15 & 7 & 18 & 36 \\
\hline Uganda & 10 & 5 & 7 & 17 & 9 & 36 & 2 \\
\hline Togo & 11 & 2 & 40 & 16 & 12 & 5 & 26 \\
\hline Burundi & 12 & 6 & 43 & 7 & 4 & 7 & 1 \\
\hline Malawi & 13 & 17 & 24 & 18 & 10 & 28 & 4 \\
\hline Guinea-Bissau & 14 & 27 & 26 & 2 & 22 & 10 & 16 \\
\hline Sierra Leone & 15 & 19 & 44 & 5 & 14 & 9 & 25 \\
\hline Sudan & 16 & 31 & 6 & 14 & 36 & 13 & 29 \\
\hline Comoros & 17 & 1 & 42 & 8 & 3 & 8 & 15 \\
\hline Senegal & 18 & 26 & 27 & 34 & 21 & 41 & 33 \\
\hline Botswana & 19 & 16 & 10 & 46 & 46 & 47 & 43 \\
\hline DR of the Congo & 20 & 35 & 47 & 6 & 34 & 2 & 18 \\
\hline Guinea & 21 & 25 & 29 & 30 & 29 & 19 & 19 \\
\hline Somalia & 22 & 13 & 46 & $\ldots$ & 38 & 1 & 22 \\
\hline Ethiopia & 23 & 12 & 20 & 4 & 15 & 20 & 3 \\
\hline Angola & 24 & 34 & 3 & 40 & 39 & 12 & 34 \\
\hline Madagascar & 25 & 28 & 38 & 25 & 32 & 34 & 12 \\
\hline Namibia & 26 & 18 & 22 & 39 & 48 & 45 & 20 \\
\hline Burkina Faso & 27 & 15 & 17 & 19 & 23 & 31 & 5 \\
\hline Mali & 28 & 23 & 16 & 9 & 42 & 27 & 17 \\
\hline Mauritius & 29 & 33 & 5 & 41 & 1 & 46 & 30 \\
\hline Mozambique & 30 & 24 & 8 & 23 & 33 & 35 & 24 \\
\hline Chad & 31 & 22 & 4 & 22 & 43 & 15 & 11 \\
\hline Congo & 32 & 37 & 34 & 42 & 40 & 11 & 44 \\
\hline Central African Republic & 33 & 36 & 39 & 3 & 44 & 4 & 27 \\
\hline Gabon & 34 & 39 & 37 & 43 & 45 & 29 & 47 \\
\hline Eritrea & 35 & 32 & 28 & 32 & 24 & 17 & 8 \\
\hline Niger & 36 & 8 & 35 & 10 & 41 & 23 & 7 \\
\hline Kenya & 37 & 29 & 32 & 24 & 19 & 32 & 14 \\
\hline Mauritania & 38 & 4 & 25 & 21 & 47 & 40 & 39 \\
\hline Djibouti & 39 & 38 & 31 & 45 & 30 & 24 & 48 \\
\hline São Tomé and Príncipe & 40 & 40 & 33 & 33 & 6 & 30 & 38 \\
\hline Seychelles & 41 & 41 & 12 & 47 & 5 & 44 & 40 \\
\hline South Africa & 42 & 42 & 19 & 44 & 26 & 48 & 46 \\
\hline Lesotho & 43 & 45 & 13 & 36 & 18 & 39 & 9 \\
\hline Côte d'Ivoire & 44 & 43 & 41 & 27 & 20 & 14 & 35 \\
\hline Gambia & 45 & 44 & 30 & 29 & 8 & 33 & 28 \\
\hline Swaziland & 46 & 46 & 21 & 38 & 17 & 21 & 10 \\
\hline Cape Verde & 47 & 47 & 2 & 37 & 11 & 43 & 45 \\
\hline Rwanda & 48 & 48 & 11 & 12 & 2 & 25 & 6 \\
\hline
\end{tabular}

Source: Based on Table 1. 


\subsection{Evidence from rank-correlation coefficients}

Table 4 below summarises the partial rank correlation coefficient. It affirms the conclusion from the previous discussion. That is rank based on average data provides no/little ground to support weak institutions, high proportion of rural population, higher economic growth, and high population density cause deforestation in SSA. It is only the share of agriculture in GDP which loosely supports the established view.

Table 4: Summary of partial rank correlation coefficients.

\begin{tabular}{cccccc}
\hline$\rho \mathrm{ar}$ & $\rho \mathrm{a} 1$ & $\rho \mathrm{a} 2$ & $\rho \mathrm{a} 3$ & $\rho \mathrm{a} 4$ & $\rho \mathrm{a} 5$ \\
\hline 0.7084 & -0.0200 & 0.0695 & 0.4188 & -0.0996 & 0.2828 \\
$\rho \mathrm{ra}$ & $\rho \mathrm{r} 1$ & $\rho \mathrm{r} 2$ & $\rho \mathrm{r} 3$ & $\rho \mathrm{r} 4$ & $\rho \mathrm{r} 5$ \\
\hline 0.7084 & -0.0200 & 0.2408 & 0.4931 & -0.1420 & 0.1324 \\
\hline
\end{tabular}

Source: Based on the Table 3

$\rho=$ Spearman's rho, a=net forest area lost, $r=$ average annual deforestation rate, $1=$ average population density, $2=$ average percentage of rural population, $3=$ average share of agriculture in GDP, 4=average economic growth rate, and 5=average government effectiveness.

\section{Conclusion}

Average empirical data from SSA was used to test the maintained hypotheses on drivers of deforestation in developing countries. However, this paper finds no strong, clear and systematic pattern to defend that population density, rural population and poverty, industrial logging, forest product export, economic growth and lack or late enactment of forest laws causes deforestation in SSA. Considering Rwanda and Zimbabwe makes the findings more vivid. Looking at the hypotheses on causes of deforestation (population density, rural poverty, percentage of rural population, agricultural share in GDP, and enactment of forest laws), one may contemplate that deforestation in Rwanda to be alarming than in Zimbabwe whereas the deforestation statistics confirms the opposite. Between 1990 and 2007 , the forest area as percentage of total land area increased by $8 \%$ in Rwanda while it decreases by in Zimbabwe $13 \%$. The annual average rate of deforestation (1990-2010), respectively, was $-1.9 \%$ in Rwanda and $1.8 \%$ in Zimbabwe. This contradicts Laurance (1999) which generalised that population pressure, weak government institutions and poor policies and industrial logging for export is the four key drivers of deforestation in tropical regions in which Africa was its sample.

The results also challenge Sieböck (2002) which strongly concluded that deforestation in SSA is mainly due to governance problems. High deforestation rate is reported in countries with better government effectiveness in the region like Botswana, Ghana, and Benin. Nor it agree with Rudel (2013) which associated lower deforestation in wetter Congo basin with the transition to minerals and oils revenues coupled with declines in agriculture and increased imports of cereals from abroad because countries with high share of oil and mineral exports in their total exports (i.e., Nigeria, Zambia, Zimbabwe of Benin, Liberia, Equatorial-Guinea and Ghana) have also scored high rate of deforestation.

Better information would have been gleaned from sub-national panel data on the loss of different forests overtime in different countries. Such data, however, is hardly available in SSA countries. Therefore, it requires SSA countries themselves to avail better research funds to detach researchers from international data and incumbent hypotheses based on studies in other developing regions like Latin America and South Asia. In addition, governments shall look beyond merely enacting specific forest laws. Law enforcements should be improved. Otherwise, the success of recent forest management initiatives such as CDM and REDD+ in the region will be under question. 


\section{References}

Arcand, J., Guillaumont, P. and Sylviane, G.J. 2008. Deforestation and the real exchange rate. Journal of Development Economics, 86(2): 242-262.

Barbier, E.B. and Burgess J.C. 2001. The economics of tropical deforestation. Journal of Economic Survey, 5(3): 412-433.

Barnes, D.F. 1990. Population growth, wood fuels, and resource problems in Sub-Saharan Africa. Energy series paper No. 26. Industry and Energy Department Working Paper. World Bank.

Boahene, K. 1998. The challenge of deforestation in tropical Africa: reflections on its principal causes, consequences and solutions. Land Degradation and Development, 9: 247-258.

Butler, R.A. and Laurance, W.F. 2008. New strategies for conserving tropical forests. Trends in Ecology and Evolution, 23(9): 469-472.

Culas, R.J. 2007. Deforestation and the environmental Kuznets curve: An institutional perspective. Ecological Economics, 61(2-3): 429-437.

de Sherbinin, A., Lopez-Carr, D., Cassels, S., Jiang, L., Lopez-Carr, A. and Miller, K. 2014. Population-environment theory and contemporary applications. Encyclopaedia of Earth. Web. http://www.eoearth.org/view/article/5378ed20cf2aafa2ccd987e. [Accessed 10 September 2014]

Deacon, R.T. 1999. Deforestation and ownership: evidence from historical accounts and contemporary data. Land Economics, 75(3): 341-359.

Diarrassouba, M. and Boubacar, I. 2009. Deforestation in Sub-Saharan Africa. Selected paper for presentation at the Southern Agricultural Economics Association annual meeting, Atlanta, Georgia, January 31, February 3.

Food and Agriculture Organization of the United Nations (FAO). 2005. Global Forest Resources Assessment 2005. FAO Forestry Paper 147. Rome.

Food and Agriculture Organization of the United Nations (FAO). 2010. Global Forest Resources Assessment 2010. FAO Forestry Paper 163. Rome.

Heston, A., Summers, R., and Aten, B. 2009. PWT6.3. Center for International Comparisons of Production, Income and Prices at the University of Pennsylvania. Web. https://pwt.sas.upenn.edu/php_site/pwt_index.php. [Accessed 24 December 2013].

Kaufmann, D., Kraay, A. and Mastruzz, M. 2013. The Worldwide governance indicators: 2013 Update. Website. www.govindicators.org. [Accessed 21 June 2014].

Matthews, E., Payne, R., Rohweder, M. and Murray, S. 2000. Pilot Analysis of global ecosystems: forest ecosystems. World Resources Institute. Washington, DC.

Mitchard, E.T. and Flintrop, C.M. 2013. Woody encroachment and forest degradation in sub-Saharan Africa's woodlands and savannas 1982-2006. Phil.Trans.R.Soc.B.2013 368.

Motel, P. 2010. Causes of deforestation. Encyclopaedia of Earth. Web. http://www.eoearthorg/view/article/150961. [Accessed 1 September 2014].

Naoto, J. 2006. International trade and terrestrial open-access renewable resources in a small open economy. Canadian Journal of Economics, 39(3): 790-808.

Nayak, P. 2004. Poverty and Environmental Degradation in Rural India: A Nexus. NEEA Annual Conference. January, Dibrugarh, Assam, India.

Organization for Economic Cooperation and Development (OECD). 2010. African Economic Outlook 2010. Paris, France.

Pearce, D.W. 2001. The Economic Values of Forest Ecosystems. Ecosystem Health. 7(4): 284-296.

Ramon, L. and Galinato, G. 2005. Trade Policies, Economic Growth, and the Direct Causes of Deforestation. Land Economics, 81(22): 145-169. 
Reusing, M. 2000. Change detection of natural high forests in Ethiopia using remote sensing and GIS techniques. International Archives of Photogrammetry and Remote Sensing. XXXIII: B7.

Rudel, T.K. 2013. The national determinants of deforestation in sub-Saharan Africa. Phil.Trans.R.Soc. B 2013368.

Shashi, K. and Berry, A.R. (eds.). 2005. Institutions, sustainability, and natural resources: Institutions for Sustainable Forest Management. Springer, Netherlands.

Shyamsundar, P., Araral, E. and Weeraratne, S. 2005. Devolution of resource rights, poverty and natural resource management: A review. Environmental Economics Series. Paper No. 104. World Bank Publisher, Washington DC.

Sieböck, G. 2002. A political, legal and economic framework for sustainable forest management in Cameroon. Concerted Initiatives to Save the Rainforests. Master Thesis (Unpublished). Lund University, Sweden.

Tietenberg, T. 2000. Environmental and natural resource economics. $\left(5^{\text {th }} e d\right)$. Addison Wesley Longman, New York.

World Bank. 2010. Millennium Development Goals. World Bank Publishers, Washington DC.

World Bank. 2013. World Bank Data Base: Agriculture and Rural Development. http://data.worldbank.org/topic/agriculture-and-rural-development. [Accessed 13 July 2014]. 